\title{
O GERENCIAMENTO DE CACHORROS ABANDONADOS ATRAVÉS DO DESIGN DE SERVIÇO
}

Mariana Aparecida Schiavon Ferreira

Universidade do Estado de Minas Gerais - UEMG

marischiavon@hotmail.com

Gilberto Almeida Junior

Universidade do Estado de Minas Gerais - UEMG

gajunior@gmail.com

Jucélia Pereira de Oliveira

Universidade do Estado de Minas Gerais - UEMG

juceliapo0803@yahoo.com.br

Resumo: O presente estudo aborda a aplicação do design de serviço como ferramenta colaborativa para o gerenciamento de cachorros que vivem abandonados nas ruas. Somente no Brasil existe mais de 20 milhões de cachorros nesta situação e, em um contexto mundial, o número cresce para mais de 750 milhões. Um único casal de cachorros abandonados pode gerar em cinco anos uma prole estimada em mais de 10 mil animais. Por passarem por dificuldades e ficarem suscetíveis a doenças, a população desses animais deve ser controlada para evitar a proliferação de doenças infectocontagiosas - zoonoses. $O$ design de serviço enquanto gerador de ações sociais permite apresentar soluções eficientes que contribuam para melhorar a qualidade de vida em sociedade. Como resultado do trabalho, será apresentado o protótipo do serviço com definições das etapas de gerenciamento da vida do animal de rua que permite o controle da população através da esterilização, abrigo, controle de zoonoses, cadastro e pronto atendimento de animais acidentados, diminuindo os problemas em áreas urbanas.

Palavras-chave: Design de serviço, gerenciamento, animais de rua, qualidade de vida.

Abstract: This paper introduce the application of service design as a collaborative tool for managing dogs who live abandoned in the streets. Only in Brazil there are over 20 million dogs in this situation and, in a global context, the number grows to more than 750 million. Single doubleabandoned dogs can generate in estimated five-year offspring over 10 thousand animals. By going through difficulties and become susceptible to disease, the population of these animals must be controlled to prevent the spread of infectious diseases - zoonosis. The service design as social actions generator allows to present efficient solutions that contribute to improving 
the quality of life in society. As result of the work, it will be presented the design service prototype with definitions of the management stages of the life of stray animal that allows control of the population through sterilization, animal shelter, zoonosis control, registration and emergency care of injured animals, reducing problems in urban areas.

Keywords: service design, management, stray dog, quality of life. 